\title{
先天股脱治療のための有空ギプス包帯法
}

\section{Application of Fenestrated Plaster Cast for the Treatment of Congenital Dislocation of the Hip.}

\author{
大 塩 直 交*
}

緒

先天性股関節脱臼（以下先天股脱）の治潦，特汇非観 血的治㯅法は A. Lorenz (1895) によつて一応確立せ られ，この方法によつて先天股脱の治潦性解決したかの 如〉見光，時来 60 余年，多くの先天股脱睍の治潦漈 して踏域光れ，現今於ても本症洁療の根幹をなしてい るという事実は何人も認める処である。此のLorenz 法 は今改的て述べる迄もなく胎曰骨頭を筧骨目内に整復

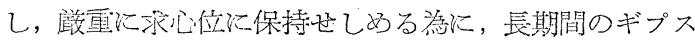

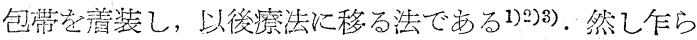
この方法は整復後骨頭の求心位保持，固定という事が過

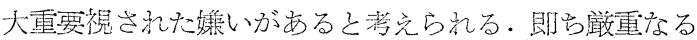
固定は骨頭の求心位保持之い5目的纪织一応達している が，その民面下肢筋肉の萎縮，関節の拘縮を起し，関節

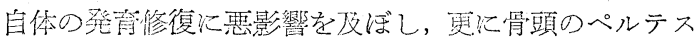
様恋形至生ずる等，二次的に局所の循澴障碍学起すと洘

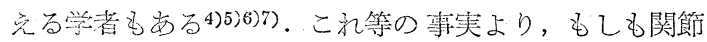
の自動渾動が骨頭水心位を保持し得ながら行われるなら

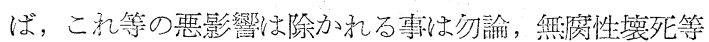

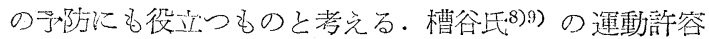

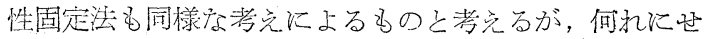

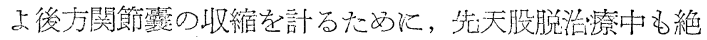
対安静の如くギプス包带のま子患胶の運動を全く澱絶し たものよりる，ギプス包带のなっ，匍い䢙り，步行を敢

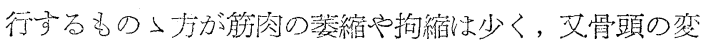
形等も少く, 後療法期間が短縮じ艮結果を得た経験が数 例飞止らない，即台先天股脱治海の要訊は大腿骨々頭が

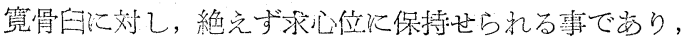
再脱臼防止のため敩重固定する必要は少く，他は自

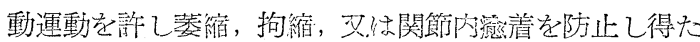
ならば，後療法も自然と容易となり短期間で良いと言う 事になると信ずる。

以上の様な胃解汇立号先天股脱治療法飞自動運動許容 を目的とした「有空ギプス包带」を考案し，昭和 32 年

* 順天堂大学医学部整形外科教室 1960 年 10 月 21 日受的
初期以降, 乳児期後半の F.O 式装具 (刮途発表) 沿療 以外のほとえぞ全ての先天股脱沿瀘汇際してこの方法を 応用しその目的を達している.今回の啹告はその一部で あり初めの 2 力年間の成續である。

\section{基礎的実験測定}

実施㳊先立ち次の样な実験測定を試反た。完全に整復 された大腿骨頭は整復後ごく早期と或る制限範囲内で大 眼骨部を運動開始せしめても, 程儿ど承心位保保持せら

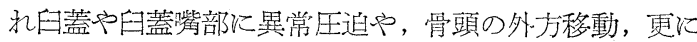
滑脱して再脱臼を菱起する事はないが，個々の症例によ りその範囲はそれぞれ異る事は勿論である。年の制限範过 田測定のため次の如き実験を行つた。

方法一脱且関節のヨード活仩よる造影法を行い，整復 後骨頭が求心位上り移動，滑脱をする状況をレ線上観 察, その範国を測定した。股脱が Lorenz 法により整 復され骨頭が求心位に位置した場合 (900 屈曲, $90^{\circ}$ 外

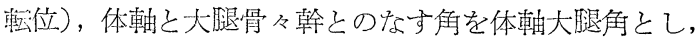
これを鋭筩化（体壁に近ずげる），鈍府化（体壁より遠 ざけ下方に下げる）セしめ，骨頭が承心的位置より移 動，再脱白を起可限界点を測定，その点をそれぞれ最少 限界角及び最大限界角と乙，骨頭が症心位置上り移動乙 始める点を測定，それぞれ最少許容盾及び最大許容盾之 した。従つてそれぞれの関係法次の様になる。

最大限界侍 $\geqq$ 最大許容侍

最少限界盾 $\leqq$ 最少許容能

先天股脱臼の中，完全脱臼（I 度～III度）30 例 41 関 節（生後6 力月〜3 年 6 力月）飞於て実施し次の結果を 得た。

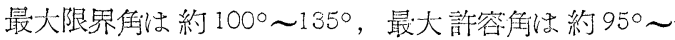
$110^{\circ}$, 最少限界角及び許容角を測定し得たるのは 6 例 7 関節であり, その結果虫最小限界触 $45^{\circ} \sim 55^{\circ}$, 最少許 容等は 550〜600であつた。但し上記症例中完全整復 不 能なもの，不良なるものを除外乙艾安定性（Stability） 不良なもの等は除外した。結果として考案される事は次 の通りである。

整復位骨頭の求心位保持許容運動䡉囲は安全度を見越 
乙て 60〜900の間，300という事とし，その範囲内で 亦れば，この種自動運動が行なわれて子骨頭の求心位保 持といら目的は保たれる仼。

\section{実 施 方 法}

先きの実験に基ずき，先ず脱目股関節に対して $25 \%$ ヨード油造影術安行い, 全麻下にて整復術を型の如く行 い，乙線上許容有を一応検討し適応を定める. Lorenz 第I 肢位ギプス包带固定を行う（実際には900 屈曲 $80^{\circ}$ $\sim 70^{\circ}$ 外転).

次淐期に（1 週以内）に大腿上面に図 1 の如く䓡を

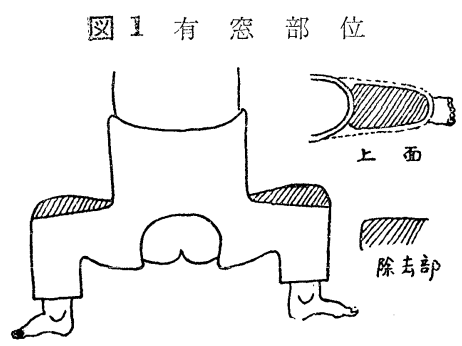

潤ける。開空する事によつて大腿部が容易に空外に出る

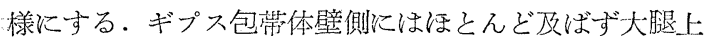
面より滕部に及ぶ。下腿のつき上げ，引き降しを行い， 低動運動を加え目的の自動楎動が可能なる事を確める。 有空処置の時期については次の如き経験により一定に定 めた。

始好約 20 例 (29 関節) 年令江 6 力月乃至 5 年 8 力月

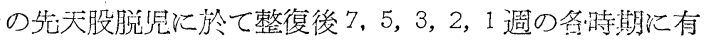
空化処置を施し，その成績を検討した結果，比䡥的早期 飞有空化を行い，許容性自動運動を行なわしめる方が骨 萎縮, 筋萎縮及び関節拘縮も少く, 㕛後療法も比較的短

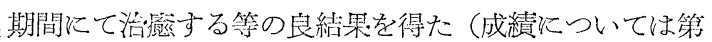
31 回日本整形外科学会総会にて発表した). か子る傾问 を少数例ではあるが知る事が出来たので，その後全症例 共整復後, ギプス包带の乾燥学待ら, 約 5 日万琹 1 週目 勆有空化を施行する事と定好。

図 2 U. (のびトり)

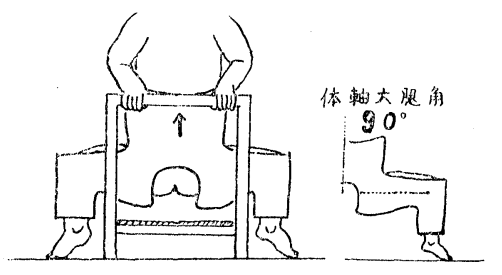

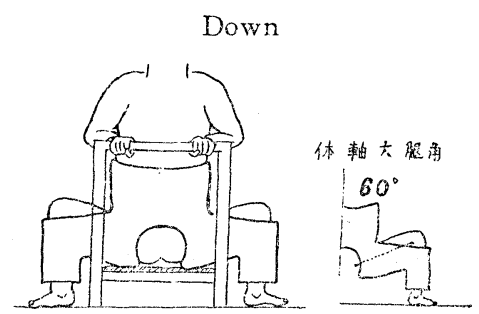

图 $3 \quad U_{p}$

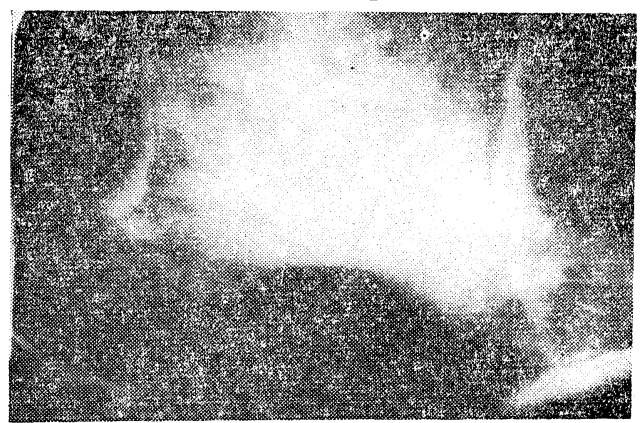

Down

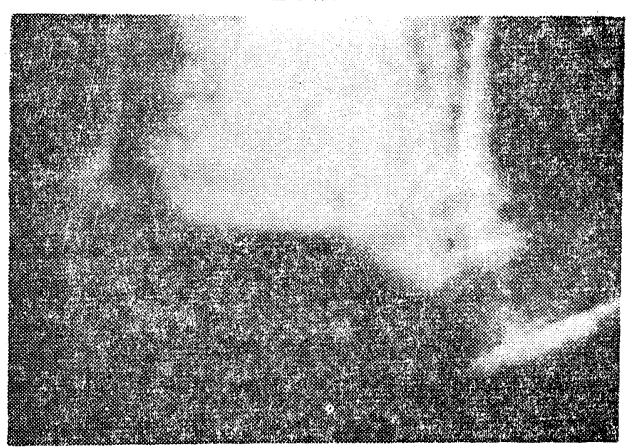

図 4.

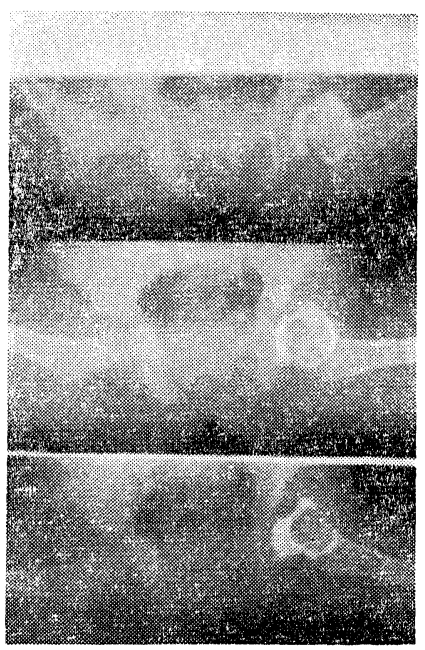


図 5

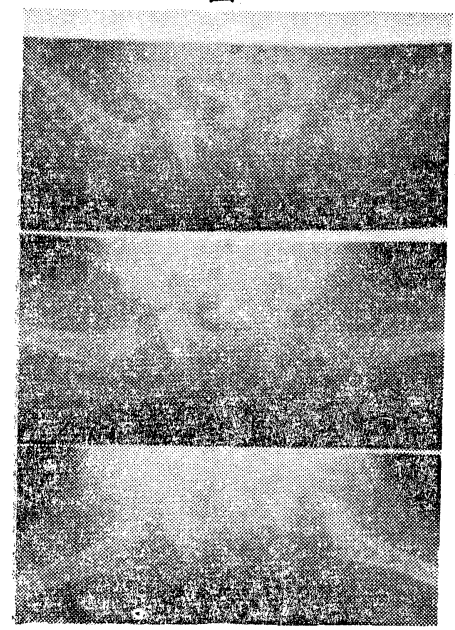

図 6
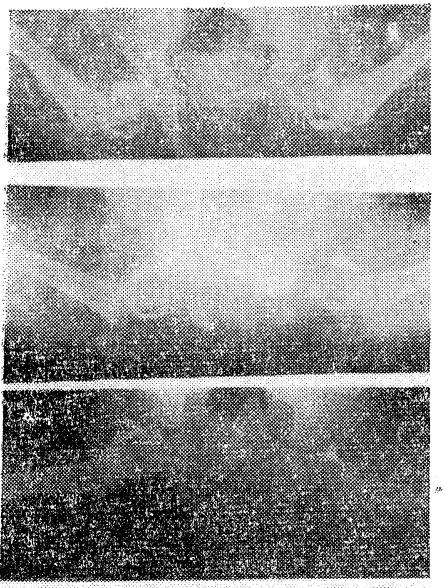

図 7

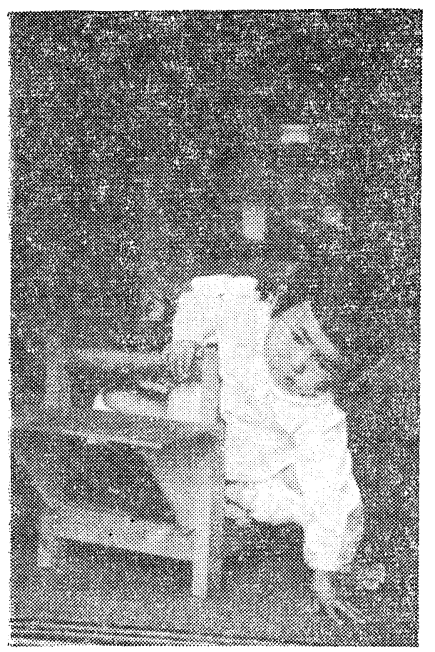

次に先天股脱用椅子に入れ，座ぶとんを坐部に特き自 動運動によつてギプス包带の下面の破損をす防する。こ の椅子に坐した患児は図 2 の如くUp. Down の仰び上 り運動を行う事が出来, 背㰧位をとらして必脚の伸晨, 屈曲を行い得る、棸匍い回る事も可能となる。これ等の

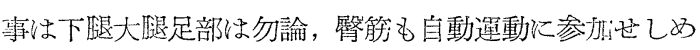

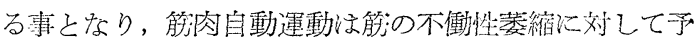
防的作用守るもの亡い党よう。

\section{症例亡成續}

昭和 32 年初期より同 33 年 12 月迄に 那須整形外科診 療沂注て実施せる症例は 76 例 122 関節で，年令は生

表 1 症例数之関節数

\begin{tabular}{|c|c|c|c|c|c|}
\hline 年令 & 1才未満 & 2才未满 & 3才未満 & 3才以上 & 訫 \\
\hline $\begin{array}{l}\text { 例 } \\
\text { (関節数) }\end{array}$ & $\begin{array}{c}34 \\
(56)\end{array}$ & $\begin{array}{c}32 \\
(50)\end{array}$ & $\begin{array}{c}8 \\
(13)\end{array}$ & $\begin{array}{c}2 \\
(3)\end{array}$ & $\begin{array}{c}76 \text { 例 } \\
\text { (122関節) }\end{array}$ \\
\hline 両 側 & 22 & 18 & 5 & 1 & 46例 \\
\hline$J_{T}^{J^{\prime}} \quad$ 側 & 12 & 14 & 3 & 1 & 30 例 \\
\hline
\end{tabular}

表 2 脱臼度別区分

\begin{tabular}{|c|c|c|c|c|c|}
\hline 年令 & 1才未満 & 2才未満 & 3才未汧 & 3才以上 & 竐 \\
\hline 两脱臼 & 11 & 5 & 2 & 1 & 19 \\
\hline I 度 & 24 & 17 & 4 & 0 & 45 \\
\hline II 度 & 13 & 18 & 5 & 1 & 37 \\
\hline III 度 & 8 & 10 & 2 & 1 & 21 \\
\hline 計 & 56 & 50 & 13 & 3 & 122 関節 \\
\hline
\end{tabular}

後 5 力月万至 5 才 8 カ月の先天股脱罗である (表 1,2).これは治療終了後約 1 力年以上の経 過を観察する事の出来た症例である。1 尔末:

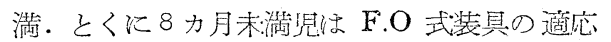
でなからたものであり，2お以上の10 例 16 関

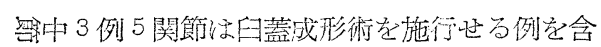
んでいる.

成績深先ずギプス包带有空化による竍容自動 運動を寒施したる成績を検討するためにギプ 不包带除去時, 即方整復後約 2 力月半万至 4 力 月半の時期に判定し，文炎の各々については治 療終了時及び最終観察時の 3 つの時期に判定

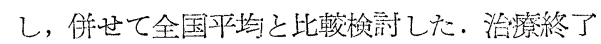
時に於行る判定基準は表 3 の如くレ線学的之機 能的成績之 2 つの面上り判定した（表 4, 5,6). 


\section{表 3 成績判定基準}

a) V線学的基準

A. 骨頭整復位, 骨頭頸部に異常を認めない, 又は 臼蓋形成の徵候の良好なるもの。

B. 骨頭整復位, 骨頭, 頸部飞軽度の異常のある るの，又は目蓋形成の徵候の多少認められるも の.

C. 骨頭整復位，骨頭頸部に中等度の異常のあるも の, 又は臼蓋形成の徴候のほとんど認められぬ もの。

D. 骨頭整復位, 骨頭頸部に高度の異常のあるも の, 又は骨頭非整復位（再脱曰）.

b) 機能的基準

I筊菱縮, 又は拘縮の源とんぞ無きか, 又は軽度 なるもの。

II 觔萎縮又は拘縮が中等度のもの。

III 筋菱縮又心拘縮が高度にして立分なる拺察法を 必要とするもの。

虹 4 レ線学上成績

\begin{tabular}{|c|c|c|c|c|c|}
\hline $\begin{array}{l}\text { 年令 } \\
\text { 成績 }\end{array}$ & 1才洼 & 2才嘴 & 3才未洼 & 3才以上 & 壾 \\
\hline $\mathrm{A}$ & 32 & 35 & 8 & 0 & $64(52.4 \%)$ \\
\hline$B$ & 11 & 18 & 5 & 1 & $36(29.5 \%)$ \\
\hline $\mathrm{C}$ & 8 & 7 & 0 & 0 & $15(12.3 \%)$ \\
\hline $\mathrm{D}$ & 5 & 2 & 0 & 0 & $7(5.7 \%)$ \\
\hline
\end{tabular}

機能上成績

\begin{tabular}{|c|c|c|c|c|c|}
\hline 令 & 1才未満 & 记未満 & 3才未満 & 3才以上 & 詁 \\
\hline I & 45 & 40 & 7 & 0 & $92(75.4 \%)$ \\
\hline II & 10 & 7 & 5 & 3 & $25(20.5 \%)$ \\
\hline III & 1 & 3 & 1 & 0 & $5(4.1 \%)$ \\
\hline
\end{tabular}

璱 6 有空ギブス包帶除去時所見

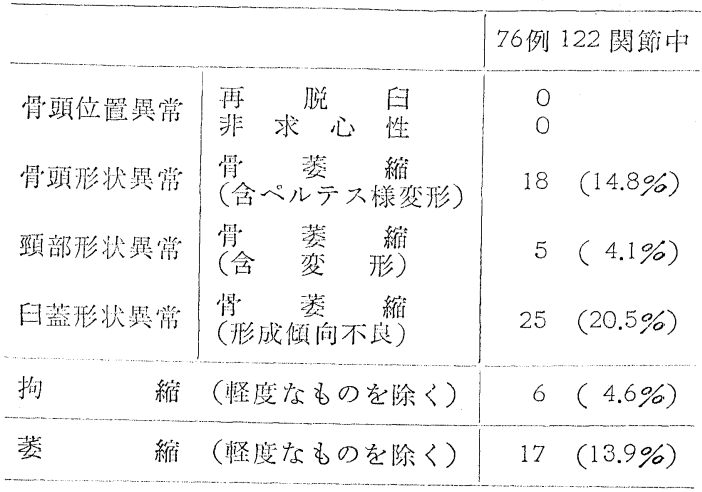

表 7

\begin{tabular}{|c|c|c|c|}
\hline & $\begin{array}{c}\text { 治療終了時 } \\
76 \text { 例 } \\
122 \text { 関節 }\end{array}$ & \begin{tabular}{|c|} 
最終観察時 \\
76 例 \\
122 関節
\end{tabular} & $\begin{array}{l}\text { 全国統計 } \\
\text { (1 年後) } \\
6466 \text { 例 }\end{array}$ \\
\hline 臼 & 0 & 0 & $9.3 \%$ \\
\hline 脱 & $3(2.5 \%)$ & $1(0.8 \%)$ & $1.9 \%$ \\
\hline ペルテス様変形 & $13(10.7 \%)$ & $10(8.1 \%)$ & $13.1 \%$ \\
\hline 縮 & $18(14.8 \%)$ & $5(4.1 \%)$ & \\
\hline 臼蓋形成不全 & $14(11.5 \%)$ & $7(5.7 \%)$ & $20.4 \%$ \\
\hline 頸 部 変 形 & $9(7.4 \%)$ & $7(5.7 \%)$ & $5.0 \%$ \\
\hline 縮 & $5(4.1 \%)$ & 0 & $5.9 \%$ \\
\hline 縮 & $16(13.1 \%)$ & $3(2.5 \%)$ & \\
\hline
\end{tabular}

\section{考按}

先天股脱治淲に際して再脱臼防止のためにいたずらに 䈯重な固定包蒂を実施しているが，も乙早朝より整復さ れた骨頭が求的位置を保持しながら，或る程度の自動

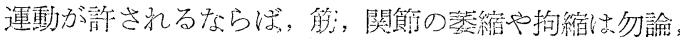

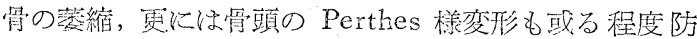
止乙得るのではないかと考光，自動運動許容性の有空ギ

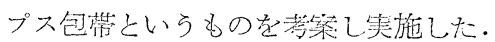

その成續を检討すると全ての先天股脱の治澽成續仙年

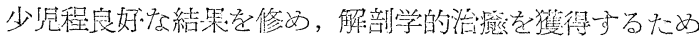
飞早期治療という事が強調されているが，著者の成績に 於てる全く同様な事が云える。この成續について個々検 討を折光て見ると次の様な結果之なつた。

1）骨頭位置異常，亜脱臼

整復時, 多少骨頭の求心性が不满足であつても, 有空 ギプス包带によつて竍容性自動運動を行かせて見ると数 週後にはレ線像上潤足出来:万求心的位置を獲得した症例

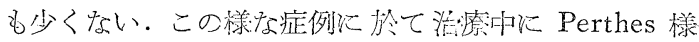

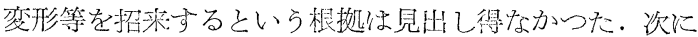

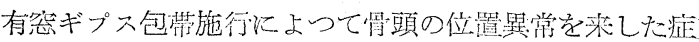
例は皆舆で市つたが，海㖠終了時に於ては3関節に亜脱

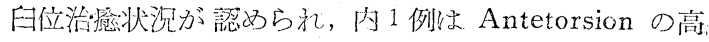
度のものであつた。

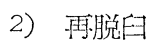

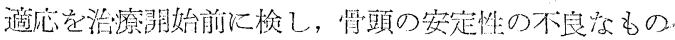
卆除外したつわか皆無.

3）骨頭形状異常，骨頭等縮，Perthes 様变形

有空ギプス包带除亡侍，レ線像上骨頭の変形，绻縮を

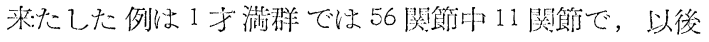
Perthes 様变形に進璒したもの入大部分を含又, 整復後

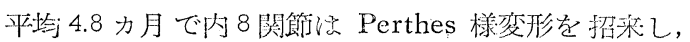
更に 8 関節中 3 関節はとの後钲部は萎縮が発現して内反 
股に進展した。この3 関節の症例は内転符の拘縮が高度 で高度脱臼の症例であつた。

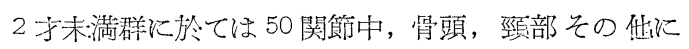
、骨萎縮を招来したものは 15 関節で, Perthes 様変形, 内反股等に進展したもの9関節である. Perthes 椂変形 の発現は平均 5.2 カ月であつた.

2 才以上の群では骨頭, 頸部の骨萎縮は症例が少なか つたが相当高率に発現した. 然し乍ら Perthes 様変形, 内反股等に進展したものは皆無であつた。

骨萎縮の夕で止まつた症例は治潦終了時, 最終観察時

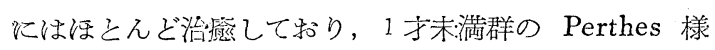
変形も治癒傾向は早期に認められたが, これに反し 2 才 未満の群では治癒傾间低く, Perthes 様变形は大部分最 終観察時价於ても変形を貽し, 日蓋急峻及び亚脱位治癒 に進展する傾向を示した。

然し乍ら, 高度 Perthes 様变形即ち骨頭分節化, 消 失等は僅かであり, 1 才満群に於て 3 関節, 2 才末満群 飞於て 4 関節に止まつた. Perthes 様変形を䂆方する目 的で許容自動運動性の有空ギプス包带を考案したのであ るが, 該病変の原因が未だ明確でない現在, これを防止 する事は不可能であつた。然し乍ら従来の方法で治療し た著者等の経験比にして比輘的低率に止まり, 特に高度 Perthes 栐変形は僅少であつた事は早期の許容自動運動 が有効であり，Perthes 様变形等の杼方にも意義がある と信ずるものである.

4）覮骨目蓋形成

年少是に於ては比較的良好な結果を見る事が出来, 年 長児に於ては必しも良好々は云光ず，又高度脱臼の方が 軽度脱曰に比し恢復状況が不良の様に思われたが, 数値 的に明か注す事は困㐨であつた。然し本法は曰蓋修復 機檕汇少くとも好影響があるものと云光よう。

5）解萎縮

麻痺合併例を除筋菱縮は大半の症例にごく軽度であ

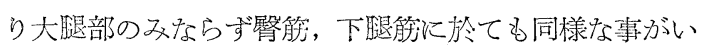
える.多少萎縮の認められた症例でも後潦法期間は短か くて恢復し, 洽療終了時に於て認められた症例は16関 節で以後放置し, 最終観察時には3 関節に過ぎなかっ

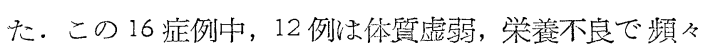
小巟科的疾患の罹患者であつた事を附記する。

\section{6) 拘 縮}

外転䚣拘緧は軽度乍ら有空プブス包带施行時に於て認 められたが, 後療法必須という症例は僅少であり, 最終 観察時にも存したものは皆無である.

\section{結語}

著者は幼照先天股脱の治潦法に関して「有空ギプス包 帯」なるものを考案しその年法について述べ，昭和 32 年以降 33 年迄の間に 76 例, 122 関節に実施し, その治 潦成䋶について検討を相えた。

1）有空ギプス包罒は整復骨頭が賽骨的に刘して求心 的位置を保ち乍ら，或る程度の自動運動老許容する。元 の筙囲は約 600 900 (体朝大腿角) でその間約 300 で ある・

2）この自動運動許容によつて関節拘縮, 筋菱縮は相 当程度予防可能にして, この事は後燎法期間の短縮化に 利がある。

3）先天股脱沿療中，相当高率の瀕度にて合併する骨 頭, 頸部及び臼蓋等の骨菱縮変形等の発現は有空ギプス 包帯による治潦法によつて比較的低率に止奶, 更に Perthes 様変形の発現を予防する事は不能であつたが比較 的経度に止京り，先の発現率も低率河する事が出来た。

4) 臼蓋形成汇関しては良好な結果を得たと信じられ るが本治潦法によつて特に良好であつたという結諭は出 せなかつた。

5）ギプス包带の一部に有空部が存するために，往々 ギプス包带着装中に見らる、皮膚の湿疹、汗疱疹等の発現 を相当予防出来，特に夏期に於て明瞭であつた。

6）有空化によつてギプス包带の破損の危険等は特に 認められなかつた。

7）本法は極めて簡易な処置である.

8）本法施行の時期はなる可く早期を必用とし，ギプ 父包带の硬化を待ち 1 週以内に行う必要がある。

稿を終るにあたつて, 御指導, 御校閲を賜つた恩 師福島正教授に深く感謝する。

要旨忤第 31 回整形外科学会総会に於て発表した。

\section{文献}

1) 飯野: 外科誌, 17, 225 262, 昭 30 .

2) 水町：日整会誌, 27,441 , 昭 28 .

3) 天児他：整形外科最近の進歩, 1 １8.

4) 竹沢：日整会誌, 11, 327, 昭 12 .

5) Ponseti, I. V.: J. B. J. S. 26, 775, (1944).

6) 松浦: 日整会誌, 2, 52, 昭 3 .

7) 片山：日整会誌, 17, 610, 昭 18.

8) 糟谷: 整外誌, 8 (6), 369, 昭 31 .

9）糟谷：日整会誌, 25,144 , 昭 26 .

10）福島：日整会誌，18, 1359, 昭 19. 


\section{参考文献}

1) Ponseti, I. V.: J. B. J. S. 41-A 823 (1959).

2) Pavlik, A.: Z. f. Orthop. 89, 341 (1957).

3) Mercer, W.: Ortopedic Surgery, Edward
Arnold. (1950).

4) 野崎: 整外誌, 8, 376, 昭 3I。

5) 三木：外科誌，20，129。

\section{Surmmary}

The application of ordinary plaster cast after manipulative reduction of congenital dislocation of the hip may result in unfavorable complications such as atrophy and contruture of soft tissue followed by deformities of bone and incomplete formation of acetabulum. To prevent these complications the auther used fenestrated plaster cast, the technique of which is described in detailf in this paper.

After the application of the ordinary plaster cast in frog position a large opeing extending from groin to below knee in the antsrior aspect of each thigh. The opening allow some leg motion while holding the femoral head tight in the acetabulum. The allowance of the active movement in the hip is considered to give good results in avoiding the complications of the soft tissue ead osseous deformation. $95.4 \%$ of the studied 76 cassnshowed good resnlts in view of functional recovery and $81.9 \%$ were resulted in excellent anatomical improvement. The allowance of some motion of the leg and femoral head in this type of fixation is suppoed to be responsible for the above good resulos.

Departmemt of Orthopedic Surgery, Juntendo Uuiversity, Shool of Medicine 